\title{
Structure-property correlation on AA 2219 aluminium alloy weldments
}

\author{
P SRINIVASA RAO, K G SIVADASAN and P K BALASUBRAMANIAN \\ Materials and Metallurgy Group, Vikram Sarabhai Space Centre, Trivandrum 695022, India \\ MS received 3 May 1995; revised 2 January 1996
}

\begin{abstract}
AA 2219 aluminium alloy is the material proposed for the construction of tanks for liquid cryogenic fuels like liquid oxygen and liquid hydrogen, in Indian launch vehicle programmes. To meet the material requirement, ISRO has developed the alloy AA 2219 indigenously on an industrial scale. Process development and structure-property correlation of auto TIG weldments of AA 2219 Al alloy reported in this paper establishes that postweld reaging of AA 2219 weldments in T62 condition enhances both strength and ductility.
\end{abstract}

Keywords. AA 2219 aluminium alloy; cryogenic fuel tank; auto TIG welding; postweld reaging; structure-property correlation.

\section{Introduction}

Aluminium alloy AA 2219 is the most used material for the construction of liquid cryogenic rocket fuel tanks. It has a unique combination of properties such as its good ability to weld, high strength to weight ratio and superior cryogenic properties. AA 2219 aluminium alloy has already been successfully used in various launch vehicle systems such as Saturn V, Apollo, Space Shuttle etc. and is the material selected for Ariane $V$ and for substituting AFNOR 7020. The cryogenic tankage being supplied to India by Russia is also using AA 2219 for the liquid hydrogen tank. Pressure vessels of AA 2219 aluminium are usually re-heat treated after welding or used in the as welded condition. The T81 and T87 tempers (table 1) are recommended for assemblies to be left in the as welded conditions.

Assemblies to be re-heat treated after welding, may be welded in ' $F$ ' condition (Robinson et al 1962). For better weld efficiency the most desirable weld/heat treating sequence is solution treatment and aging after welding. The use of this sequence may be prohibited for large tanks due to distortion and quenching problems which can occur during solution treatment. Another methodology of weld sequence is a post-weld aging. However, there are contradictory reports about ductility of weldments. Hence, further studies are required to optimize the re-aging sequence for better ductility (Material data handbook on AA 2219, 1972).

AA 2219 was neither produced nor used till recently in India and now has been indigenously developed on an industrial scale. Plates and sheets of width up to $1.5 \mathrm{~m}$ have already been produced in India. It proposes to use indigenously produced AA $2219 \mathrm{Al}$ alloy for cryogenic fuel tank.

A technological programme has been evaluated to establish weld parameters for welding of AA 2219 alloy sheets and plates. Emphasis is on studying the effects of post-weld reaging treatment on the properties of weldment. This paper deals with the structure-property correlation on auto TIG weldments of AA $22193 \mathrm{~mm} \mathrm{Al}$ alloy sheets. The welding technology has already been published elsewhere (Vinod Kumar et al 1994). 
Table 1. Tempers and aging treatments for AA 2219 alloy.

\begin{tabular}{ll}
\hline Temper & Description \\
\hline F & As fabricated \\
T31 & Solution heat treat + stretch \\
T37 & Solution heat treat $+8 \%$ cold work \\
T4 & Solution heat treat \\
T62 & T4 aged $36 \mathrm{~h}$ at $190^{\circ} \mathrm{C}$ \\
T81 & T31 aged $18 \mathrm{~h}$ at $177^{\circ} \mathrm{C}$ \\
T87 & T37 aged $24 \mathrm{~h}$ at $163^{\circ} \mathrm{C}$ \\
\hline
\end{tabular}

Table 2. Chemical composition.

\begin{tabular}{lllllll}
\hline & \multicolumn{7}{c}{ Elements (wt \%) } \\
\cline { 2 - 6 } Material & $\mathrm{Cu}$ & $\mathrm{Mn}$ & $\mathrm{Zr}$ & $\mathrm{V}$ & $\mathrm{Ti}$ & $\mathrm{Al}$ \\
\hline AA2219 & 6.3 & 0.38 & 0.2 & 0.1 & 0.06 & bal \\
AA2319 & 6.25 & 0.36 & 0.2 & 0.12 & 0.13 & bal \\
\hline
\end{tabular}

\section{Materials and experimental methods}

The chemical composition of 2219 sheet and 2319 filler wire as analysed by XRF method is shown in table 2.

The $3 \mathrm{~mm}$ thick AA 2219 aluminium alloy sheets used in this study were produced indigenously and heat treated to T62 temper involving solution treatment at $535^{\circ} \mathrm{C}$ and water quenching and artificial aging for $36 \mathrm{~h}$ at $190^{\circ} \mathrm{C}$. Auto TIG welding was accomplished using POLY SOUDE SAF FRANCE - $360 \mathrm{~A}$ Welding Machine.

The weldments were sectioned, polished and etched using Keller's reagent for metallographic examination. A Reichert MeF optical microscope was used to examine the weld quality that included porosity, weld interface and grain structure. A Vicker's microhardness tester was used to determine the hardness profile along the weld at a load of $100 \mathrm{~g}$. Tensile specimens were cut transverse to the weld, with the weld bead in the centre. Tensile tests were carried out using Model INSTRON Universal Testing Machine. Tensile fractures were observed using Stereo Scan $250 \mathrm{Mk} 3 \mathrm{Model}$ scanning electrou microscope (SEM) for fractographic analysis.

\section{Results and discussion}

Mechanical properties and microhardness values of the as-welded samples are compared with parent metal properties in table 3.

Since the dominant factor governing all significant thermal events in welding is the energy input which affects the peak temperature distribution and solidification time, metallurgical considerations favour low energy heat input. It can be anticipated that tensile properties of low heat input (condition D of table 3) would be highest due to reduced total thermal exposure and thereby better metallurgical characteristics. 
Table 3. Efficiency and microhardness in as welded condition.

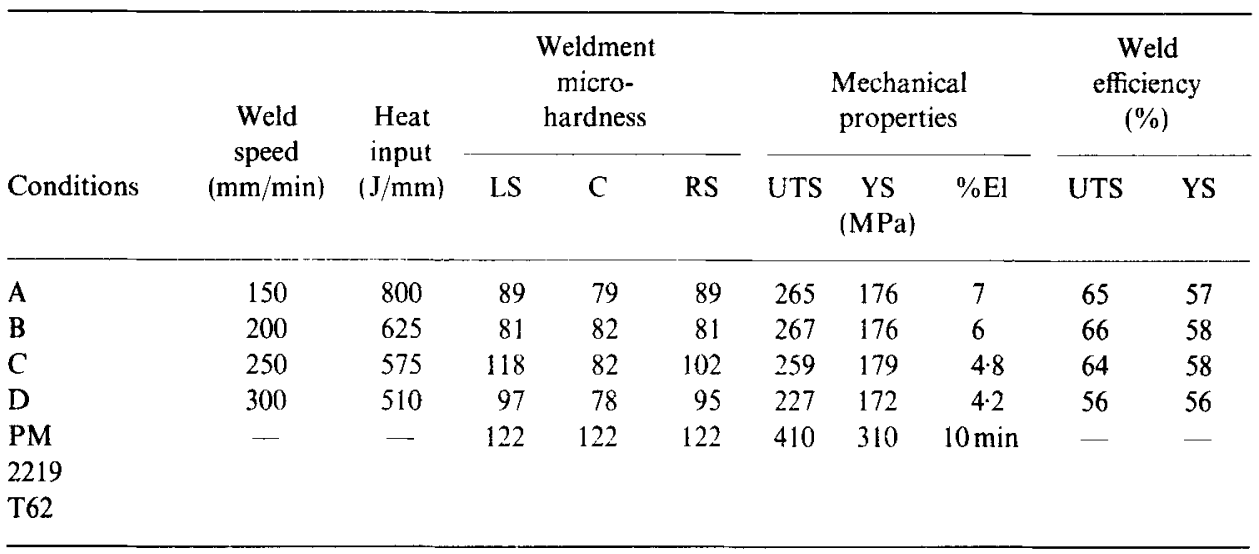

LS, Left hand side; RS, right hand side; C. centre of weld: PM, parent metal.

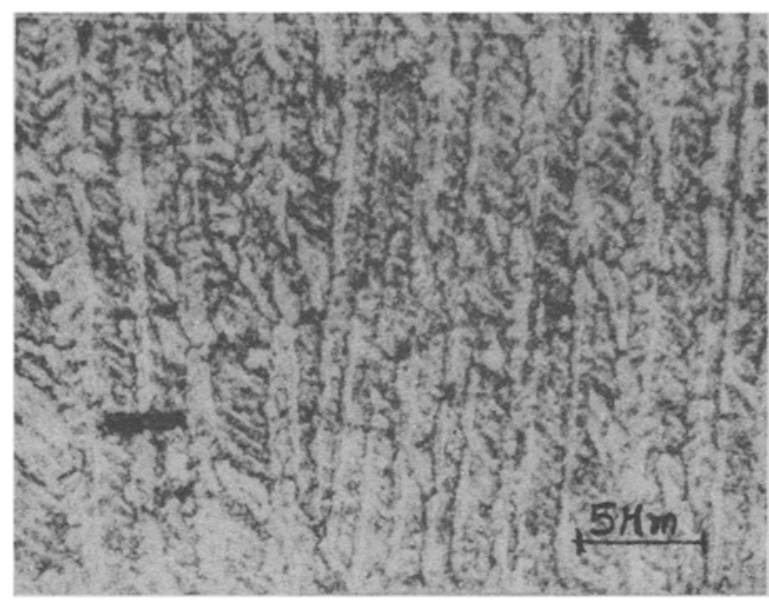

Figure 1. Microstructure of condition D at the centre of the weld. Solute banding with twinning is seen.

However, this was not the case as shown by the tensile test results (table 3), which indicated the lowest weld efficiency of $56 \%$ for this weldment. The weld failure occurred at the centre of the weld. The poorer properties can be attributed to generally observed tear drop solidification geometry at higher weld speeds which in turn results in solute banding as shown in figure 1 . As a general rule, higher welding speed results in heavy solute banding as the rate of solidification fluctuates more cyclically above and below a mean value of solidification rate (ASM Welding handbook 1983). The solute band is clearly evident at the centre of the weld which solidifies at the end. The fractograph of the tensile fracture (figure 2) exhibits delamination of solute rich and solute poor bands, as analysed by EDAX, with fine dimples of ductile mode fracture on band free structure. The weld structure away from the centre of the weld is not banded but is more dendritic (figure 3a). The weld bead heat affected zone (HAZ) interface shown in figure 4 exhibits cellular structure with uniformly distributed $\mathrm{CuAl}_{2}$ precipitates as confirmed by 


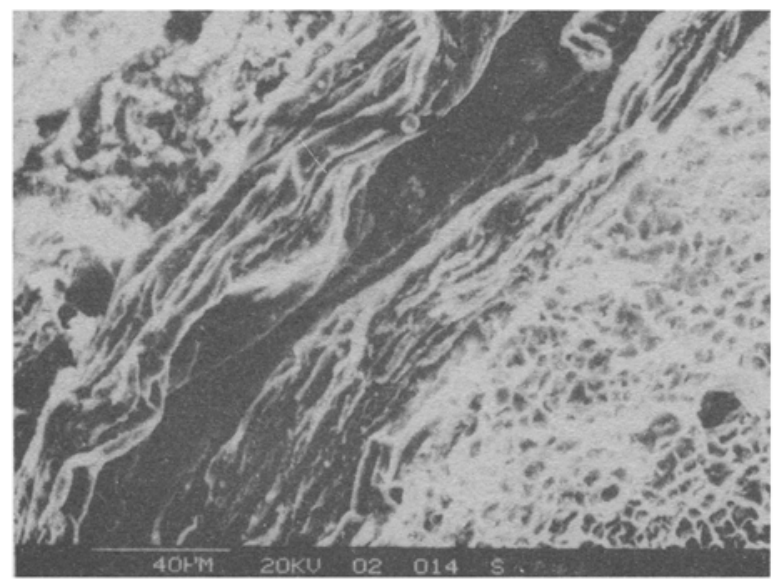

Figure 2. Fractograph of condition D weldment.
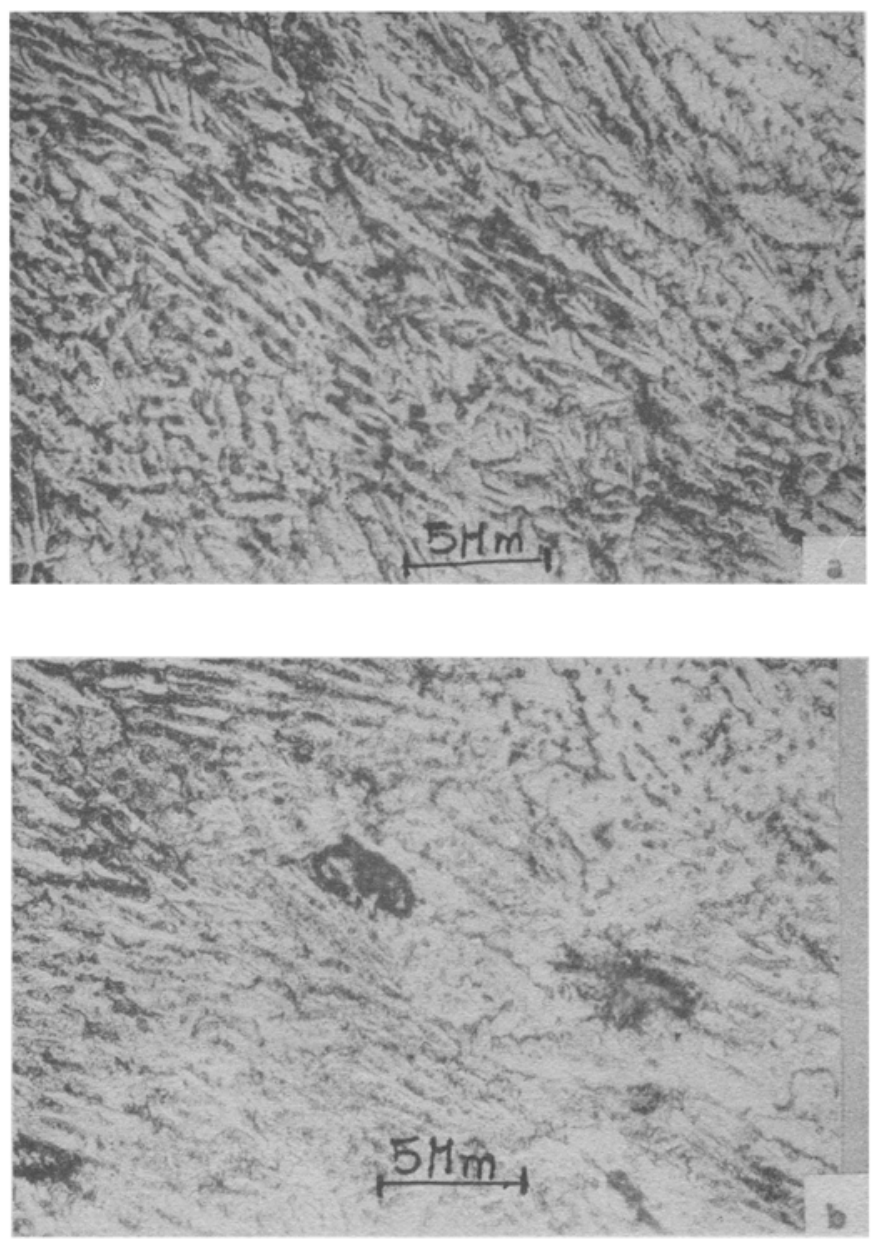

Figure 3. 

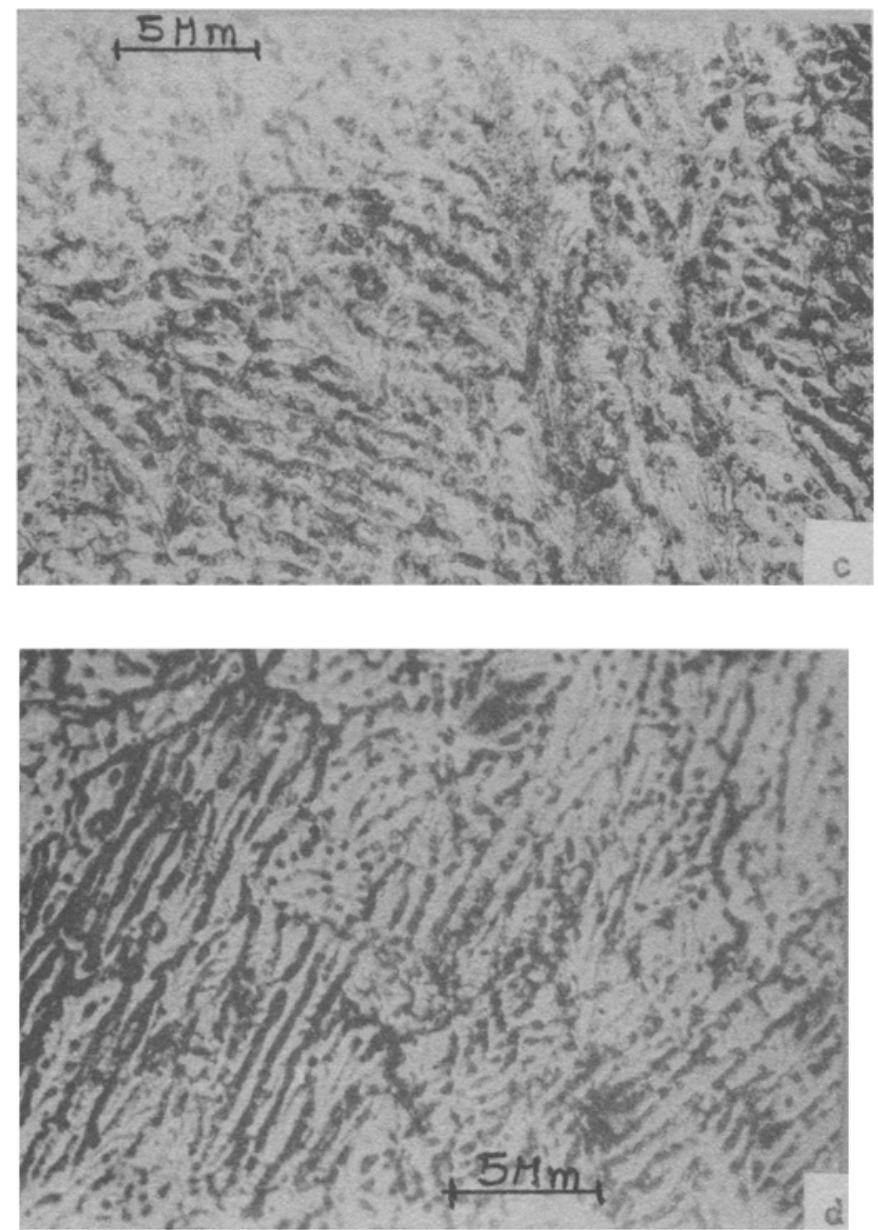

Figure 3. Microstructure of weldments: a. condition D. b. condition C. c. condition B and d. condition $\mathrm{A}$.

EDAX. Such a structure is preferred to brittle banded structure, for better mechanical properties. In the case of condition $\mathrm{C}$ (table 3 ) the weld efficiency was marginally better than condition $\mathrm{D}$ but elongation was again not significant. The tensile specimen failed in HAZ region and not in the weldment unlike in the former case. The microstructure of weldment (figure 3 b) indicates fine dendritic structure with no banding. The microstructure of $\mathrm{HAZ}$ region as shown in figure 5 indicates partial grain boundary melting causing brittle eutectic structure. Large porosity of about $30 \mu \mathrm{m}$ size were also observed in $\mathrm{HAZ}$ region. This could be the reason for the failure of the samples in $\mathrm{HAZ}$ region. Pores have also contributed to loss of ductility. The fractograph shown in figure 6 indicates secondary cracks in the grain boundaries and a mixed mode of fracture.

Conditions A and B have shown similar mechanical properties and are superior to the other two sequences with better ductility. Tensile specimen in both the conditions failed in the weldment. The microstructure of condition $B$ (figure $3 \mathrm{c}$ ) is more fine and uniform than condition $\mathrm{A}$ (figure $3 \mathrm{~d}$ ). Microhardness variations within the weldments 


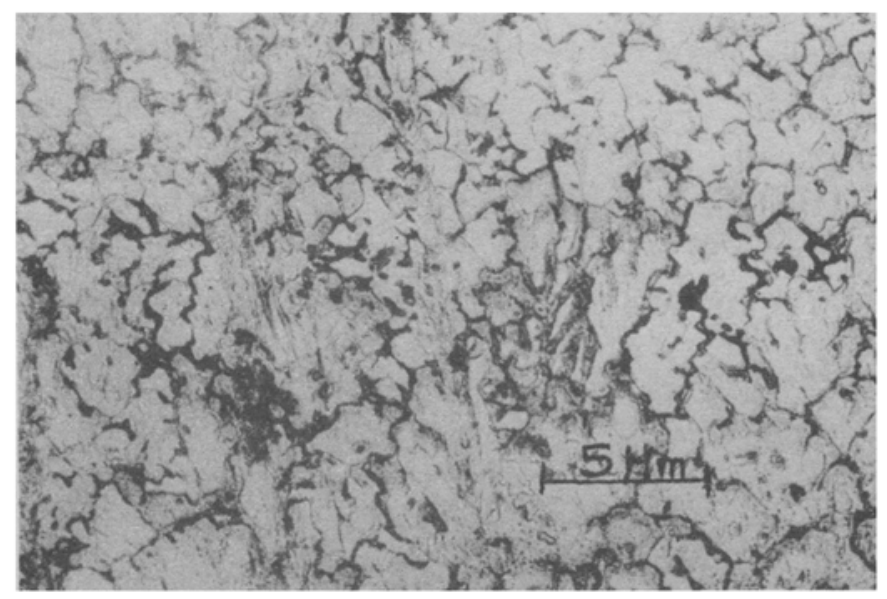

Figure 4. Microstructure of condition D HAZ.

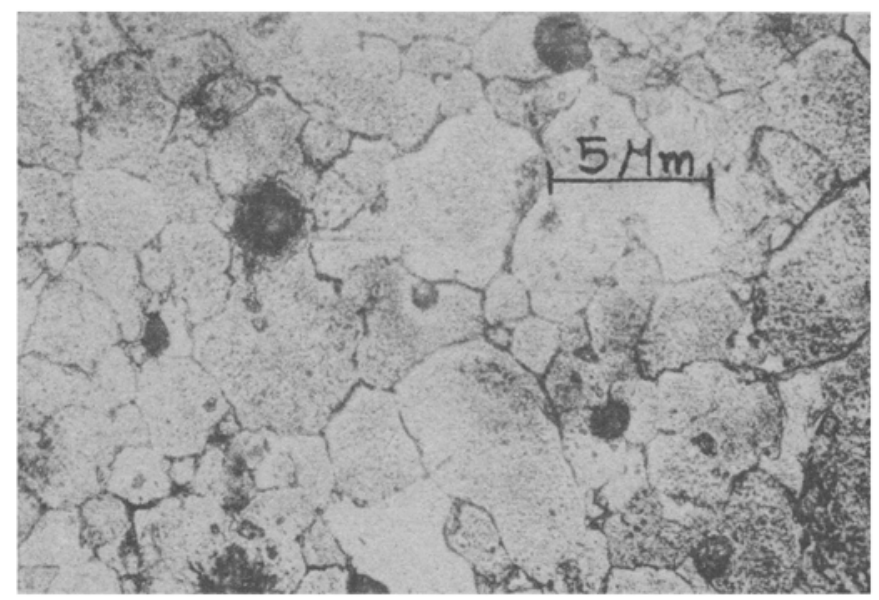

Figure 5. Microstructure of condition C HAZ.

is minimum in condition B as compared to condition A. The fractographs of both the conditions shown in figures 7 and 8 show ductile mode of failure.

From the above observations it is understood that condition B with weld speed of $200 \mathrm{~mm} / \mathrm{min}$ is most optimum under present experimental conditions. Weld samples of this condition have been subjected to various reaging treatments as shown in table 4.

The term reaging is used here to represent additional stage aging after welding of already aged material (T62 condition). Reaging time was varied from $6 \mathrm{~h}$ to $30 \mathrm{~h}$ at the aging temperature of $190^{\circ} \mathrm{C}$. The properties of post-weld aged samples are also shown in table 4 . It was observed that post-weld aging for $18 \mathrm{~h}$ gives the highest weld efficiency of $80 \%$ UTS and $84 \%$ YS with no significant drop in ductility. However, the tensile specimens failed within $\mathrm{HAZ}$ and not within the weldments after the reaging treatment. This indicates that reaging treatment resulted in significant strengthening of the weldments. The weld strength increases from $267 \mathrm{MPa}$ to beyond $328 \mathrm{MPa}$ by 


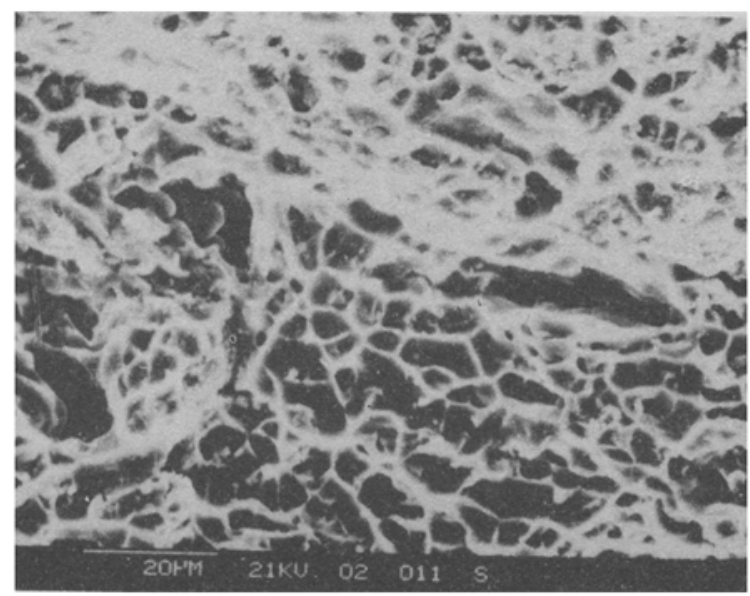

Figure 6. Fractograph of HAZ/weldment interface condition $\mathrm{C}$.

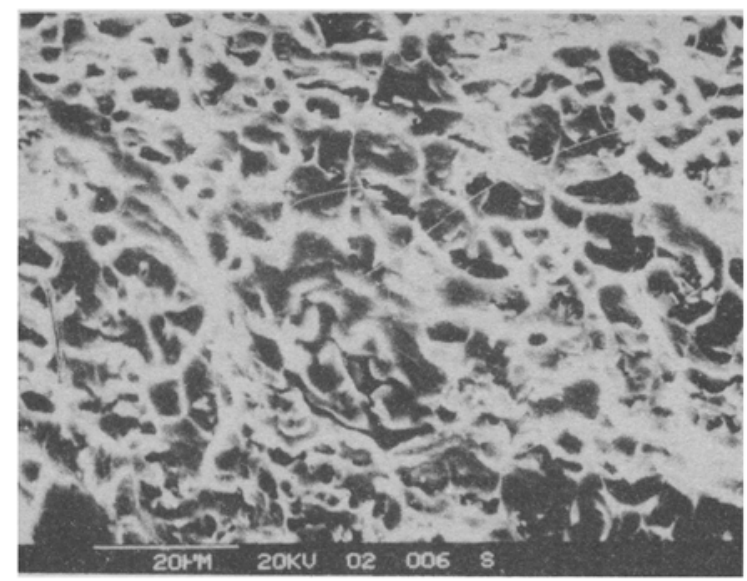

Figure 7. Fractograph of condition $\mathbf{B}$ weldment.

reaging treatment. Reaging has not caused any deterioration of properties in the parent metal.

The failure in $\mathrm{HAZ}$ region is due to the fact that both weldment and parent metal are stronger than the HAZ. The weakness of the HAZ is quite possibly due to overaging during welding, and reaging did not have any influence on HAZ. In a previous report (Trazil and Hood 1969) it was mentioned that post-weld aging results in loss of ductility, the weld sequence used was solution treatment-welding-aging. In this sequence, structure in the solution treated condition, prior to welding, contains GP zones and $\theta^{\prime}$. During welding, the GP zones and $\theta^{\prime}$ revert to solid solution and, subsequently, $\theta$ precipitates out, preferentially at grain boundaries in the $\mathrm{HAZ}$ region (Dumolt et al 1981). This reduces the ductility. Further aging after welding does not enhance properties of HAZ. The failure on these samples should have presumably occurred within HAZ with overaged coarse precipitates at grain boundaries, resulting in loss of ductility. Hence, it can be concluded that solution treatment-welding-post-weld 


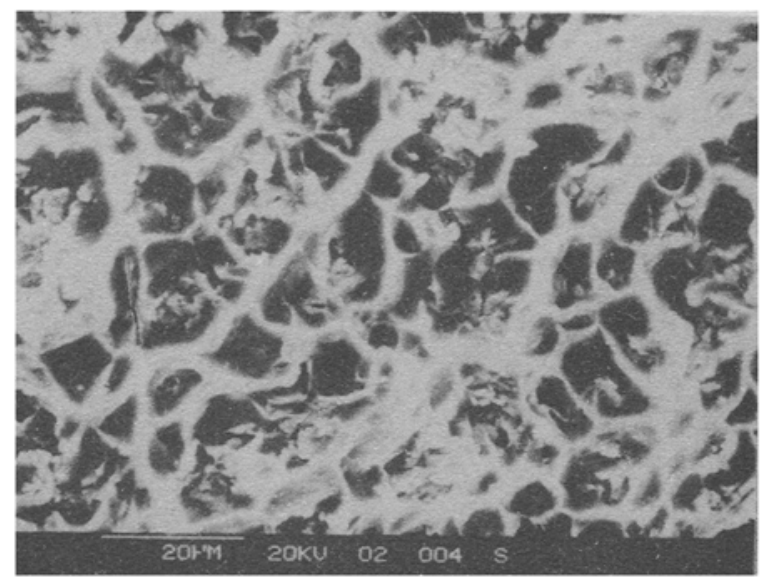

Figure 8. Fractograph of condition A weldment.

Table 4. Effect of reaging on weldments (condition B, table 3).

\begin{tabular}{|c|c|c|c|c|c|c|}
\hline \multirow{2}{*}{$\begin{array}{l}\text { Reaging } \\
\text { time } \\
\text { (h) }\end{array}$} & \multirow[b]{2}{*}{$\begin{array}{c}\text { Hardness } \\
\text { BHN }\end{array}$} & \multicolumn{2}{|c|}{$\begin{array}{c}\text { Mechanical } \\
\text { properties }\end{array}$} & \multirow[b]{2}{*}{$\% \mathrm{El}$} & \multicolumn{2}{|c|}{$\begin{array}{c}\text { Weld efficiency } \\
(\%) \\
\text { (wrt PM } 2219 \text { in T62) }\end{array}$} \\
\hline & & $\begin{array}{l}\text { UTS } \\
\text { (MPa) }\end{array}$ & $\begin{array}{c}\mathrm{YS} \\
(\mathrm{MPa})\end{array}$ & & UTS & $Y S$ \\
\hline 30 & 112 & 287 & 232 & 5 & 70 & 75 \\
\hline 24 & 113 & 316 & 248 & 5 & 77 & 80 \\
\hline 18 & 117 & 328 & 260 & 6 & 80 & 84 \\
\hline 14 & 115 & 254 & 202 & 4 & 62 & 65 \\
\hline 10 & 111 & 221 & 192 & 6 & 54 & 62 \\
\hline 8 & 110 & 246 & 195 & 5 & 60 & 63 \\
\hline 6 & 110 & 246 & 189 & $3 \cdot 5$ & 60 & 61 \\
\hline
\end{tabular}

aging sequence is not recommended for AA 2219 alloy. However, partial reaging after welding in $\mathrm{T} 62$ condition enhances strength without the loss of ductility.

\section{Conclusions}

(i) A weld speed of $200 \mathrm{~mm} / \mathrm{min}$ is optimum and gives weld efficiency of $65 \%$ on UTS, in the as welded condition.

(ii) Reaging after welding in T62 condition improves weld efficiency by progressive strengthening of weldment by aging.

(iii) Post-weld reaging for $18 \mathrm{~h}$ was found to be optimum with better weld efficiency of $80 \%$ on UTS but without any sacrifice in weld ductility.

\section{Acknowledgements}

The authors thank the staff members of Materials and Metallurgy Group, RPFF and QDCC for extending the facilities of heat-treatment, fabrication, welding, metallography, 
non-destructive testing and materials testing. The authors are also grateful to Shri M C Mittal, Head, SMD, Dr K V Nagarajan, Group Director, MMG and Director, Vikram Sarabhai Space Centre for their interest.

\section{References}

ASM Welding Handbook 61983 9th edition pp 28-35

Dumolt S D, Laughlin D E and Williams J C 1981 Proc. of the first international aluminum welding conference, Cleveland, Ohio (eds) R A Kelsey and C R Felmley Jr. pp 115-135

Material Data Handbook Aluminum Alloy 22191972 2nd Edn Western Applied Research \& Development Inc.

Robinson I B, Collins F R and Dowd J D 1962 Welding J. 422215

Trazil J P and Hood D W 1969 Welding J. 48395

Vinod Kumar C, Sivadasan K G, Kurup M S, Kothandaraman G and Balasubramanian P K 1994 National welding seminar, Jamshedpur, India pp 5-11 